\title{
PENGEMBANGAN STRATEGI PEMBELAJARAN YANG EFEKTIF DI TENGAH PANDEMI COVID 19
}

\author{
Tantri Yulia \\ (Dosen Prodi Magister Teologi Sekolah Tinggi Teologi Kristus Alfa Omega Semarang: \\ tantri703@gmail.com)
}

\begin{abstract}
Covid 19 pandemic has caused changes in various fields, including education. There are some problems that arise in the selection of learning strategies during the Covid 19 pandemic. The research method used in this research is development research, namely research used to test product quality using quantitative methods as the primary method and examining users with qualitative methods as secondary methods. The result of the research is the level of the development of effective learning strategies during the COVID-19 pandemic at STT

Kristus Alfa Omega Semarang in the moderate category or less of the maximum value is not proven.
\end{abstract}

Key Word: Development, Learning strategy, COVID 19, Effectiveness.

\section{A. PENDAhULUAN}

Di masa pandemi COVID 19, interaksi dosen dan mahasiswa tidak bisa lagi dilakukan dengan tatap muka secara langsung. Oleh karena itu, strategi pembelajaran yang didasarkan pada pertimbangan interaksi dosen dan mahasiswa secara daring perlu dikembangkan dalam menyikapi situasi pandemi COVID 19.

"Strategi pembelajaran online (daring) kegiatan belajar mengajar yang tidak terikat waktu, tempat dan ritme kehadiran dosen, serta dapat menggunakan sarana media elektronik dan komunikasi. Ada tiga tipe pembelajaran online yaitu pertama pembelajaran tidak langsung (asynchronous), dalam strategi pembelajaran ini mahasiswa membaca materi atau bahan yang lengkap dan mengerjakan kuis atau tes. Tipe kedua, pembelajaran langsung (synchronous) yaitu sebuah kelas yang dipertemukan secara online alam situs web yang telah ditentukan dan waktunya disesuaikan dengan kesepakatan bersama dengan semua mahasiswa dan dosen. Mereka semua akan masuk log in ke dalam situs bersama dengan semua mahasiswa dan dosen. Ketiga, pembelajaran campuran (blended learning) yaitu penggabungan asynchronous dan synchronous."

Strategi pembelajaran daring ini merupakan strategi pembelajaran yang menggunakan teknologi. Lebih lanjut, pembelajaran di era revolusi industri 4.0 ini diidentikkan dengan pembelajaran dengan menggunakan teknologi. Hal ini juga berpengaruh dalam penggunaan strategi pembelajaran yang digunakan oleh pendidik. ${ }^{2}$ Strategi pembelajaran ini tidak lagi dibatasi oleh ruang dan waktu. Strategi pembelajaran dengan menggunakan teknologi ini harus diimbangi dengan penguasaan metode dan media pembelajaran yang sesuai.

${ }^{1}$ Dewi Salma Prawiradilaga, Mozaik Teknologi Pembelajaran: E-Learning (Jakarta: Prenadamedia Group, 2016), 110-112.

${ }^{2}$ Abdul Muis, 'Konsep dan Strategi Pembelajaran di Era Revolusi Industri 4.0 (Yogyakarta: Laksana, 2019), 101-102. 


\section{Tujuan Pembelajaran}

Tujuan pembelajaran menjadi acuan bagi dosen dalam melaksanakan perkuliahan. "Tujuan pembelajaran (instruction) merupakan akumulasi dari konsep mengajar (teaching) dan konsep belajar (learning). Penekanannya terletak pada perpaduan antara keduanya, yakni kepada penumbuhan aktivitas subyek didik". ${ }^{3}$ Tujuan pembelajaran diharapkan mampu menumbuhkan aktivitas mahasiswa dalam aspek kognitif, metakognitif dan afektif serta psikomotorik. Aspek keterampilan atau psikomotorik yang ditekankan dalam pembelajaran masa kini antara lain keterampilan berpikir kritis, pemecahan masalah (kreatif), komunikasi dan kolaborasi.

Keterampilan berpikir kritis merupakan keterampilan untuk melakukan berbagai analisis, penilaian, evaluasi, rekonstuksi, pengambilan keputusan yang mengarah pada tindakan rasional dan logis. Kreatifitas merupakan keterampilan untuk menemukan hal baru yang belum ada sebelumnya, bersifat orisinil, mengembangkan berbagai solusi baru untuk setiap masalah dan melibatkan kemampuan untuk menghasilkan ide-ide yang baru, bervariasi dan unik. Keterampilan berkomunikasi merupakan keterampilan untuk mengungkapkan pemikiran, gagasan, pengetahuan atau informasi baru baik secara tertulis maupun lisan. Keterampilan kolaborasi keterampilan bekerja bersama secara efektif dan menunjukkan rasa hormat kepada anggota tim yang beragam, melatih kelancaran dan kemauan dalam mengambil keputusan yang diperlukan untuk tujuan bersama. ${ }^{4}$ Tujuan pembelajaran kemudian disusun secara sistematis dalam materi ajar. Tujuan dari pembelajaran akan memberikan arah kemana pembelajaran ini akan dibawa dan untuk apa pembelajaran ini dilaksanakan. ${ }^{5}$ Tujuan pembelajaran ini dipaparkan dengan jelas agar mudah dipahami dan dicapai selama masa perkuliahan.

Dalam perkuliahan tatap muka pencapaian tujuan pembelajaran dapat dengan mudah dicapai tanpa halangan yang berarti. Namun di masa pandemi COVID 19 ini pencapaian tujuan pembelajaran menjadi tantangan tersendiri bagi dosen. Tujuan pembelajaran ini dapat tercapai dengan bantuan teknologi. Dosen juga memberikan arahan yang diperlukan bagi mahasiswa dalam menuntaskan perkuliahan.

\section{Materi Pembelajaran}

Pengembangan materi ajar dapat dilakukan oleh dosen dengan berbagai cara, antara lain dosen menguasai materi ajar yang akan disampaikan, dosen rajin mengikuti seminar-seminar tentang pengembangan bahan ajar sesuai bidang yang ditekuni, dan dosen memiliki koneksi dengan rekan sejawat di dalam maupun di luar kampus melalui sharing berkaitan dengan bidang yang ditekuni. Pengembangan materi ajar yang dilakukan oleh dosen diwujudkan dalam penyusunan buku ajar. Buku ajar adalah naskah yang ditulis oleh dosen dalam rangka menunjang materi pokok mata kuliah yang

\footnotetext{
${ }^{3}$ Moh Suardi, Belajar dan Pembelajaran (Yogyakarta: Deepublish, 2018), 17. 36.

${ }^{4}$ Kenang Kelana, Pedagogik dan Covid 19 (Jakarta: Taman Pembelajar Rawamangun, 2002)

${ }^{5}$ I Ketut Sudarsana, Covid 19: Perspektif Pendidikan (Yayasan Kita Menulis, 2020), 49.
} 
diajarkan. Hal ini dapat dilihat dari cara menyusun, penggunaanya dalam pembelajaran dan teknik penyebarannya. ${ }^{6}$ Dosen yang melakukan pengembangan materi ajar dengan menyusun buku ajar akan memiliki keterampilan memperbarui informasi sesuai dengan bidangnya. Dosen juga dapat memanfaatkan video tentang materi ajar. Bahan ajar berbasis audiovisual (video) merupakan salah satu strategi pembelajaran yang efektif dapat meningkatkan pemahaman belajar, serta meningkatkan minat belajar mahasiswa. Dalam pembuatan bahan ajar audiovisual (video) sangat diperlukan suatu keterampilan mengoperasikan alat, dapat berupa software ataupun aplikasi gratis (opensource). ${ }^{7}$ Materi ajar yang disampaikan dosen disesuaikan dengan kondisi perkuliahan online, dengan memanfaatkan teknologi akan memudahkan mahasiswa untuk memahami. Dosen dituntut melakukan upaya yang lebih agar mahasiswa mampu memahami materi ajar yang disampaikan dosen.

\section{Metode Pembelajaran}

Metode pembelajaran yang dapat digunakan dalam pembelajaran secara daring adalah metode ceramah, metode diskusi, metode demonstrasi, metode resitasi, metode pemecahan masalah, metode discovery dan inquiry. ${ }^{8}$ Metode ceramah adalah metode yang digunakan dalam proses pembelajaran dengan cara penyampaian pesan. Dosen dapat menggunakan metode ceramah ini mea secara langsung atau lisan. Metode ceramah dalam masa pandemi dapat dilakukan dengan menggunakan video, dimana dosen dapat menyampaikan penjelasan materi. Metode diskusi adalah suatu cara penyajian materi kuliah dengan menugaskan mahasiswa atau kelompok belajar untuk melaksanakan percakapan ilmiah untuk mencari kebenaran dalam rangkan mewujudkan tujuan pembelajaran. ${ }^{9}$ Metode diskusi ini dapat membantu mahasiswa untuk aktif dan terlatih untuk mengembangkan pemikiran yang logis dan mengembangkan sikap demokratis dalam berpendapat. Penggunaan metode diskusi ini dapat memanfaatkan aplikasi LSM (Learning Management System), zoom meeting atau aplikasi lainnya.

Metode demonstrasi dilakukan dengan cara memperagakan barang, kejadian, aturan dan urutan melakukan kegiatan, baik secara langsung maupun melalui penggunaan media pengajaran yang relevan dengan pokok bahasan atau materi yang sedang disajikan. ${ }^{10}$ Metode ini dapat dilakukan dengan menggunakan media video guna memberikan penjelasan. Metode demonstrasi juga dapat menggunakan power point sehingga menimbulkan minat mahasiswa dalam mengikuti perkuliahan.

Metode resitasi adalah mahasiswa melakukan resume materi ajar, kemudian resume diserahkan kepada

${ }^{6}$ Cakti Indra Gunawan, Pedoman Menulis Buku Ajar dan Referensi Bagi Dosen Malang: (IRDH, 2017), 14.

${ }^{7}$ Didiek Hari Nugroho, Panduan Praktis Membuat dan Memublikasi Video Bahan Ajar Yogyakarta: (Yogyakarta: Deepublish, 2018), 1.

${ }^{8}$ I Ketut Sudarsana, Covid 19: Perspektif Pendidikan (Yayasan Kita Menulis, 2020), 49.

${ }^{9} \mathrm{H}$ Darmadi, Pengembangan Model dan Metode Pembelajaran dalam Dinamika Belajar Siswa (Sleman: Deepublish, 2017).

${ }^{10}$ I Ketut Sudarsana, Covid 19: Perspektif Pendidkan (Yayasan Kita Menulis, 2020), 50. 
dosen pengampu. Melalui penyusunan resume ini dosen dapat menilai kemampuan mahasiswa dalam menyusun kalimat. Metode ini dapat mengembangkan kepercayaan diri mahasiswa dan menumbuhkan tanggung jawab mahasiswa. Dosen memiliki tanggung jawab untuk melakukan checking apakah resume hasil karya mahasiswa atau hanya sekedar copy paste.

Metode pemecahan masalah adalah sebuah metode yang bertujuan untuk melatih mahasiswa agar memiliki kemampuan dalam menemukan solusi yang diperlukan dalam mengatasi. Metode pemecahan masalah. Metode pemecahan masalah pada dasarnya terkait dengan penggunaan pendekatan metode ilmiah yang terdiri dari langkah-langkah sebagai berikut; mengidentifikasi masalah dan komponen-komponennya, menulis hipotesis, mengumpulkan dan menganalisis data, merumuskan solusi yang diperlukan melakukan ujicoba terhadap solusi yang dipilih, dan menarik kesimpulan. ${ }^{11}$ Tujuan penggunaan metode ini adalah untuk meningkatkan kemampuan mahasiswa dalam memecahkan masalah yang dihadapi sehingga mahasiswa memiliki kemandirian. ${ }^{12}$ Metode ini diharapkan dapat meningkatkan motivasi, kemampuan kognitif dan meta kognitif mahasiswa. Pemecahan masalah yang dilakukan dosen bergantung pada pengetahuan yang dimiliki untuk membantu mahasiswa dalam melakukan penyelesaian masalah. Penggunaan metode pemecahan masalah ini juga memiliki persyaratan yaitu mahasiswa memiliki kemampuan dalam merumuskan masalah, menyusun hipotesis dan melakukan analisa serta menarik kesimpulan.

\section{Evaluasi}

Salah satu bagian dosen dalam pengembangan strategi pembelajaran adalah melakukan evaluasi bagi mahasiswa. ${ }^{13}$ Evaluasi ini memberikan gambaran, mendeskripsikan informasi, dan melakukan penilaian guna pengambilan keputusan berkaitan dengan hasil belajar mahasiswa. Prinsipprinsip evaluasi pembelajaran adalah berkesinambungan atau terus-menerus dan komprehensif yaitu dosen melakukan evaluasi secara utuh. Informasi yang diterima harus mencerminkan suatu keutuhan dari seorang peserta didik. Selain itu, evaluasi juga perlu dilakukan dengan adil, obyektif dan kooperatif di mana dosen membutuhkan rekan dosen yang lain, orang tua bahkan masyarakat. Prinsip praktis juga perlu dilakukan dalam melakukan evaluasi yaitu kegiatan evaluasi tidak seharusnya membuat mahasiswa sulit memahami. ${ }^{14}$

\footnotetext{
${ }^{11}$ Benny A. Pribadi, Desain dan Pengembangan Program Pelatihan Berbasis Kompetensi Implementasi (Jakarta: Prenada Media Grup, 2014), 135.

${ }^{12}$ Hellen Askell-Williams, Janice Orrell, "Problem Solving For Teaching and Learning" (London: Taylor and Francis Ltd, 2019), 5.

${ }^{13}$ M.Ilyas Ismail, Asesmen dan Evaluasi Pembelajaran (Makassar: Cendikia Publisher, 2020), 2020), 29-30.

${ }^{14}$ Yahya Hairun, Evaluasi dan Penilaian dalam Pembelajaran (Yogyakarta: Deepublish,
} 
Evaluasi pembelajaran yang dilaksanakan dengan prinsip-prinsip yang tepat akan mengukur kemampuan mahasiswa dengan tepat. Evaluasi pembelajaran akan menumbuhkan kepercayaan mahasiswa kepada dosen. Evaluasi pembelajaran juga menunjukkan perhatian dosen kepada mahasiswa sehingga mahasiswa memperoleh dorongan untuk berprestasi. Evaluasi pembelajaran ini juga akan memberikan masukan bagi dosen untuk meningkatkan kinerja. Evaluasi adalah penilaian terhadap hasil atau implikasi dari kegiatan pengukuran. Evaluasi didahului dengan kegiatan pengukuran dan penilaian. Pengukuran membandingkan pengamatan dengan kriteria, penilaian menjelaskan dan menafsirkan hasil pengukuran, sedangkan evaluasi penetapan nilai atau implikasi suatu perilaku baik perilaku individu atau lembaga. ${ }^{15}$

\section{Dosen}

Dosen memahami berbagai perannya dalam penerapan strategi pembelajaran sebagai pembimbing, yang memiliki tanggungjawab untuk membantu mahasiswa dalam proses pembelajaran. Sebagai pembimbing, dosen memiliki tanggungjawab untuk mengarahkan mahasiswa untuk melakukan tugas dan tanggungjawabnya. Topik pembimbingan ini mencakup masalah proses pembelajaran dan masalah lain yang sedang dihadapi oleh mahasiswa. Dosen sebagai pembimbing akan mengedepankan tangungjawabnya dalam mendampingi mahasiswa, apabila mahasiswa mengalami kesulitan dalam proses pembelajaran akan menyediakan diri untuk membantu. Dosen juga akan memeriksa tugas mahasiswa dan memberikan masukan yang diperlukan untuk meluruskan atau memberikan pandangan yang lebih luas bagi mahasiswa.

Dosen juga berperan sebagai fasilitator, yang memfasilitasi mahasiswa dalam proses pembelajaran. Sebagai fasilitator, dosen juga membantu mahasiswa agar mengalami kemudahan dalam proses pembelajaran. Pembelajaran secara daring memerlukan penggunaan teknologi informasi. Dosen dapat menjalankan fungsinya sebagai fasilitator apabila dosen memiliki sikap adaptif terhadap penggunaan teknologi. ${ }^{16}$ Dosen harus memiliki kompetensi yang diperlukan. Kompetensi adalah perilaku yang rasional untuk mencapai tujuan yang dipersyaratkan sesuai dengan kondisi yang diharapkan. Kompetensi ini merupakan kemampuan sorang dosen dalam melaksanakan kewajiban secara bertanggungjawab dan layak. ${ }^{17}$ Pada masa pandemi COVID 19 ini, dosen dituntut untuk memiliki perilaku rasional yaitu mengubah cara pandangnya tentang penerapan strategi pembelajaran yang sebelumnya dan menyesuaikannya dengan strategi pembelajaran masa pandemi Covid 19 yaitu strategi pembelajaran secara daring.

13.

${ }^{15}$ Ilyas Ismail, Assesmen dan Evaluasi Pembelajaran (Makassar: Cendekia Publisher, 2020),

${ }^{16}$ Ridwan Sanjaya, 21 Refleksi Pembelajaran Daring di Masa Darurat (Semarang: UNIKA Soegijapranata, 2020), 39.

${ }^{17}$ Suyanto Asep Jihad, Menjadi Guru Profesional (Jakarta, Essensi Erlangga Group:2013), 1. 
Peran dosen yang lain yaitu sebagai komunikator. Hal yang sangat penting untuk dilakukan dalam pembelajaran daring adalah komunikasi yang efektif antara dosen dan mahasiswa. Komunikasi yang efektif harus dibangun melalui komunikasi dua arah antara dosen dan mahasiswa. Dosen tidak hanya sekedar memberikan materi dan tugas tetapi harus memberikan konfirmasi dan umpan balik kepada mahasiswa. ${ }^{18}$ Selain itu, dosen juga berperan sebagai motivator. Konteks pembelajaran masa pandemi COVID 19 yang menuntut penguasaan teknologi informasi, menuntut motivasi yang positif dalam kuliah daring melalui materi ajar yang disampaikan melalui berbagai media. Mahasiswa dapat mengkomunikasikan ide penggunaan media dalam pembelajaran daring kepada dosen, hal ini dapat meningkatkan motivasi belajar mahasiswa. Ridwan Sanjaya berpendapat bahwa diskusi dan komunikasi mengenai perkuliahan daring penting untuk terus dilakukan. Saling memotivasi mencari sisi positif kuliah daring dan meminimalkan hambatan yang ditemui di kuliah daring harus menjadi semangat dosen dan mahasiswa guna mencapai tujuan pembelajaran. Dosen seyogyanya berusaha menjaga motivasi belajar mahasiswa dan memberikan umpan balik terhadap kemajuan dan perkembangan proses belajar mahasiswa. ${ }^{19}$

Penyesuaian dalam memilih strategi pembelajaran ini membutuhkan agility (kemampuan seseorang untuk mengubah arah dengan cepat dan tepat pada waktu bergerak tanpa kehilangan keseimbangan. Kelincahan ini berkaitan erat antara kecepatan dan kelenturan. Tanpa unsur keduanya baik, seseorang tidak dapat bergerak cepat dengan lincah) ${ }^{20}$ dalam memilih strategi pembelajaran. Dosen yang memiliki agility akan mudah untuk beradaptasi dengan situasi dan kondisi yang dihadapi serta diimbangi dengan sikap lentur atau fleksibel sehingga terjadi sinergi antara dosen dan mahasiswa dalam proses pembelajaran. Dosen juga berperan sebagai mediator dalam diskusi secara online. Dosen sebagai mediator juga menjalankan perannya dengan memberikan pujian, kritikan, dan umpan balik untuk membangun struktur kognitif mahasiswa. Dosen menolong mahasiswa mampu mengalami peningkatan kognitif mulai dari mengingat, memahami, menerapkan, menganalisis, mengevaluasi dan menciptakan sesuatu yang baru sesuai dengan kemampuan yang dimiliki oleh mahasiswa. ${ }^{21}$ Jadi peran dosen sebagai mediator lebih dari sekedar memandu jalannya diskusi kelas.

Dosen memiliki kemampuan mengembangkan keterampilan yang disebut dengan 4C skill. Keterampilan yang dibutuhkan untuk abad ke-21 adalah 4C yakni kemampuan berpikir kritis (Critical Thinking), Creativity, Collaboration dan Communication. ${ }^{22}$ Hal tersebut berarti dosen memberi tugas

\footnotetext{
${ }^{18}$ Ridwan Sanjaya, 21 Refleksi Pembelajaran Daring di Masa Darurat (Semarang: UNIKA Soegijapranata, 2020), 103.

${ }^{19}$ Ridwan Sanjaya, 21 Refleksi Pembelajaran Daring di Masa Darurat (Semarang: UNIKA Soegijapranata, 2020), 218-219.

${ }^{20}$ www.chillaword.com diakses tanggal 1 Juni 2020

${ }^{21}$ Vladimir S, Ageyev, Boris Gindis, Suzanne M Miller, Vygotsky's Educational Theory In

Cultural Context (UK: Cambridge University Press, 2003), 20.

${ }^{22}$ Jeffry Handika dkk, Pembelajaran Sains di Era Akselerasi Digital (Magetan: CV AE

Media Grafika, 2020), 69.
} 
kepada mahasiswa dengan menekankan kemampuan mahasiswa dalam berpikir kritis. Menumbuhkan kreativitas mahasiswa dapat dilakukan oleh dosen dengan cara mendorong mahasiswa untuk melakukan pendekatan yang baru dalam menyelesaikan masalah. Dosen juga memiliki kemampuan kolaborasi yaitu mampu bekerjasama dengan mahasiswa guna mencapai tujuan pembelajaran. Selain itu, dosen juga memiliki kemampuan berkomunikasi dimana dosen mampu menyampaikan ide, pertanyaan dan memberikan solusi bagi permasalahan dalam proses pembelajaran.

Dosen perlu memahami prinsip-prinsip pemilihan strategi pembelajaran masa pandemi COVID 19. Strategi pembelajaran masa pandemi COVID 19 ini dikenal dengan strategi pembelajaran daring. Munculnya sistem pembelajaran daring sebagai bentuk pemanfaatan teknologi telekomunikasi untuk kegiatan pembelajaran di tengah pandemi COVID 19 merupakan strategi yang efektif agar proses pembelajaran tetap berlangsung meskipun dari tempat yang berbeda-beda. Istilah daring merupakan akronim dari "dalam jaringan”. Jadi pembelajaran daring adalah salah satu metode pembelajaran atau dilakukan melalui jaringan internet. ${ }^{23}$

Masa pandemi COVID 19 ini menuntut strategi pembelajaran yang memanfaatkan teknologi dan telekomunikasi secara maksimal. Penggunaan teknologi dan telekomunikasi dalam pembelajaran ini mengacu pada prinsip-prinsip pemilihan strategi pembelajaran. Salah satu prinsip yang dikembangkan dalam pelaksanaan strategi pembelajaran daring adalah tidak menciptakan lebih banyak stres. Stres yang ditimbulkan dapat disebabkan oleh berbagai hal antara lain kondisi fisik yang kurang baik, kondisi ekonomi (kurangnya pemenuhan kebutuhan ekonomi), kondisi lingkungan yang terbatas, dan terutama jika tugas kepada mahasiswa diberikan dalam porsi yang berlebih dari pemberian tugas pada masa tatap muka. Berada di depan laptop dalam jangka waktu cukup lama juga dapat berpotensi memicu stres. Kurangnya daya dukung proses pembelajaran seperti koneksi internet yang tidak stabil juga dapat menjadi pemicu stress. Prinsip pembelajaran pada masa COVID 19 berikutnya adalah dosen memiliki ekspektasi yang realistis terhadap tujuan pembelajaran yang hendak dicapai. Tujuan pembelajaran yang dapat dicapai pada masa ini adalah pembelajaran yang realistis yaitu tujuan pembelajaran yang dapat dicapai sesuai dengan waktu, media dan kompetensi yang digunakan dalam proses pembelajaran. Selain itu, prinsip dalam penerapan strategi pembelajaran masa pandemi COVID 19 adalah komunikasi yang efektif antara dosen dan mahasiswa guna memperdalam materi.

\section{Mahasiswa}

Mahasiswa yang mengikuti pembelajaran daring pada masa pandemi COVID 19 ini perlu memiliki inisiatif yang tinggi dalam mengikuti proses pembelajaran. Inisiatif yang tinggi dibutuhkan untuk membawa mahasiswa dalam sebuah persepsi sebagai seorang pembelajar dan bagaimana ia berinteraksi dengan lingkungan belajarnya. Rasa inisiatif adalah salah satu manifestasi dari sebuah keyakinan atas kemampuan yang ada pada diri mereka yang tidak lain terbentuk dari konsep diri

\footnotetext{
${ }^{23}$ I Ketut Sudarsana, Covid 19: Perspektif Pendidkan (Yayasan Kita Menulis, 2020), 178.
} 
akademik. Keyakinan itulah yang mendorong mahasiswa untuk mencari dan menemukan pengalamanpengalaman baru dalam kegiatan belajarnya, seperti aktif dalam pembelajaran-pembelajaran daring. ${ }^{24}$ Inisiatif yang tinggi ini diwujudkan mahasiswa dalam berinteraksi dengan lingkungan belajarnya (baik dengan dosen maupun dengan mahasiswa yang lain). Inisiatif ini juga menunjukkan keyakinan yang tinggi mahasiswa yang memiliki konsep diri yang positif. Mahasiswa dengan konsep diri yang positif berupaya menemukan pengalaman-pengalaman baru dalam proses pembelajaran secara daring.

Selain itu mahasiswa perlu memiliki sikap mandiri yang ditunjukkan dengan belajar mandiri dan memiliki cara untuk menyelesaikan masalah yang dihadapinya. Kemandirian mahasiswa dalam pembelajaan masa pandemi COVID 19 ini dilakukan dengan penggunaan teknologi. Teknologi pendidikan memiliki potensi untuk meningkatkan produktivitas pendidikan dengan mempercepat tahapan belajar (rate of learning) yaitu membantu dosen menggunakan waktunya lebih baik dan mengurangi beban dosen dalam menyajikan informasi sehingga dosen lebih banyak membina dan mengembangkan kegairahan belajar mahasiswa. Selain itu, teknologi memberikan kemungkinan mengurangi kontrol dosen yang kaku dan tradisional sehingga memberikan kesempatan mahasiswa berkembang sesuai dengan kemampuannya. Teknologi juga memberikan dasar yang lebih ilmiah terhadap pengajaran dengan perencanaan program pembelajaran yang lebih sistematis dan pengembangan pengajaran yang dilandasi penelitian tentang perilaku. Teknologi lebih memantapkan pengajaran dengan meningkatkan kapabilitas mahasiswa dengan berbagai media komunikasi melalui penyajian informasi dan data secara lebih secara lebih konkret. Selanjutnya, teknologi memberikan materi ajar secara seketika (immediacy learning) karena dapat mengurangi jurang pemisah antara perkuliahan dan memberikan pengetahuan langsung. Teknologi memungkinkan penyajian pendidikan lebih luas dengan pemanfaatan bersama tenaga serta penyajian informasi yang menembus batas geografi. ${ }^{25}$ Penggunaan teknologi dalam pembelajaran membuka pintu bagi kemandirian mahasiswa dalam belajar. Mahasiswa bukan hanya menerima materi tetapi menemukan makna pembelajaran.

\section{Media Pembelajaran}

Strategi pembelajaran online dapat menggunakan berbagai media, antara lain:

a. Google Classroom

Google Classroom adalah produk Google dan memiliki banyak fasilitas yang akan memudahkan dosen dalam melaksanakan kegiatan pembelajaran. Pembelajaran yang dimaksud bukan hanya di kelas saja, melainkan juga di luar kelas karena mahasiswa dapat melakukan pembelajaran

${ }^{24}$ Jusuf Blegur, Soft Skill Untuk Prestasi Belajar (Surabaya: Scopindo Media Pustaka, 2020), 59.

${ }^{25}$ Yusufhadi Miarso, Menyemai Benih Teknologi Pendidikan (Jakarta: Prenadamedia Group, 2004), 6. 
dimana pun dan kapan pun dengan mengakses Google Classroom secara online. ${ }^{26}$ Kelebihan strategi pembelajaran online menggunakan Google Classroom adalah dapat terhubung dengan Gmail, Youtube dan lain-lain. Pembelajaran juga dapat dilakukan dimana pun dan kapan pun hal ini menjadikan pembelajaran menjadi fleksibel. Google Classroom memudahkan interaksi dosen dengan mahasiswa dalam kelas. Kelebihan berikutnya dari Google Classroom adalah menu yang tidak terlalu rumit, sehingga mudah digunakan oleh pengguna.

\section{b. Learning Management System}

Learning Management System adalah aplikasi berbasis web untuk kegiatan program pembelajaran elektronik (e-learning program). Karakteristik fitur yang tersedia untuk LSM institusi dosenan adalah mengelola user, role, courses, instructor, facility, course calendar, learning path, user messaging, dan notification. ${ }^{27}$ Media LMS ini memiliki sejumlah kelebihan antara lain materi yang disampaikan dapat diperbarui secara efektif dan efisien, dapat diakses darimana saja karena hanya membutuhkan akses internet, proses belajar mengajar dapat dilakukan dengan multimedia maupun ebook yang tersedia sebagai referensi dari materi yang ingin disampaikan dosen, dan dapat mengumpulkan tugas secara online dengan cara mengupload tugas yang diberikan oleh dosen secara langsung. ${ }^{28}$

c. Edmodo

Edmodo adalah perusahaan teknologi yang menawarkan platform komunikasi, kolaborasi dan pelatihan kepada sekolah dan dosen. Jaringan Edmodo memungkinkan dosen untuk berbagi konten, mendistribusikan kuis, tugas dan mengelola komunikasi dengan mahasiswa, kolega, dan orang tua. Edmodo ini terpusat pada dosen dan filosofinya. Mahasiswa dan orang tua hanya dapat bergabung dengan Edmodo jika diundang oleh dosen. ${ }^{29}$ Edmodo memberi peluang bagi dosen dan mahasiswa untuk berbagi konten, mendistribusikan kuis, tugas dan melakukan komunikasi dengan mahasiswa. Kelebihan dari Edmodo adalah dapat merencanakan seminar pengembangan profesi dengan layanan video Edmodo yaitu SchoolTube. ${ }^{30}$ Selain itu, mahasiswa dapat berkomunikasi dengan dosen maupun khusus dengan mahasiswa lainnya. Mahasiswa juga dapat menerima masukan dari dosen (hasil

\footnotetext{
${ }^{26}$ Rini Mastuti dkk, Teaching From Home: dari Belajar Merdeka Menuju Merdeka Belajar (Yayasan Kita Menulis, 2020), 63.

${ }^{27}$ Muhamad Imanudin, Membuat Kelas Online Berbasis Android dengan Google Classroom (Yogyakarta: Garudhawaca, 2018), 2.

${ }^{28}$ Ibid., 3-4.

${ }^{29}$ Daniel Agus Maryanto, Jurnal Pendidikan Empiris Edisi : Juni 2018 (Solo: CV Akademika, 2018), 52.

${ }^{30}$ Ibid., 53.
} 
koreksi dari dosen) dan orang tua dapat mendampingi mahasiswa dengan memantau hasil kerja anak, nilai-nilai mereka dan menerima informasi dari dosen. ${ }^{31}$

\section{B. METODOLOGI}

Pengembangan atau metode Research and Development adalah metode penelitian yang digunakan untuk menghasilkan suatu produk baru dan menguji keefektifan produk tersebut. ${ }^{32}$ Pengujian dalam produk dalam penelitian ini adalah strategi pembelajaran yang diterapkan oleh dosen dalam pembelajaran masa pandemi COVID 19 di Sekolah Tinggi Teologi Kristus Alfa Omega Semarang. Langkah-langkah dalam penelitian pengembangan ini adalah mempelajari temuan penelitian yang berkaitan dengan produk yang akan dikembangkan, mengembangkan produk berdasarkan temuan bidang pengujian dalam pengaturan dimana ia akan digunakan akhirnya, dan merevisinya untuk memperbaiki kekurangan yang ditemukan dalam tahap mengajukan pengujian. ${ }^{33}$ Populasi dalam penelitian ini adalah semua mahasiswa Sekolah Tinggi Teologi Kristus Alfa Omega Semarang yang berjumlah 123 orang. Peneliti menggunakan sampel sejumlah 92 responden. Lebih lanjut, 30 angket digunakan untuk ujicoba dan 62 angket digunakan untuk penelitian.

\section{PEMBAHASAN}

1. Uji Hipotesis Tahap Pertama (Temuan Produk Penelitian)

Hipotesis dalam penelitian berbunyi: $\mathrm{H}_{0}$ : Diduga pengembangan strategi pembelajaran yang efektif masa pandemi COVID 19 di Sekolah Tinggi Teologi Kristus Alfa Omega Semarang dalam kategori lebih besar dari atau sama dengan $(\geq) 60 \%$ dari nilai maksimal. $\mathrm{H}_{\mathrm{a}}$ : Diduga pengembangan strategi pembelajaran yang efektif masa pandemi COVID 19 di Sekolah Tinggi Teologi Kristus Alfa Omega Semarang dalam kategori sedang atau kurang $(<) 60 \%$ dari nilai maksimal. Pengujian hipotesis dalam penelitian ini menggunakan uji t-tes dengan menggunakan bantuan SPSS 17.0, adapun hasil yang diperoleh sebagai berikut:

\section{One-Sample Statistics}

\begin{tabular}{|l|l|l|l|l|}
\hline & N & Mean & Std. Deviation & $\begin{array}{l}\text { Std. Error } \\
\text { Mean }\end{array}$ \\
\hline skor_total & 62 & 83.97 & 12.698 & 1.613 \\
\hline
\end{tabular}

${ }^{31}$ Daniel Agus Maryanto, Jurnal Pendidikan Empiris Edisi : Juni 2018, 58.

${ }^{32}$ Budiyono Saputro, Manajemen Penelitian Pengembangan (Yogyakarta: Aswaja Pressindo, 2011)

${ }^{33}$ Tatik Sutarti dan Edi Irawan, Kiat Sukses Meraih Hibah Penelitian Pengembangan (Yogyakarta: Deepublish, 2017), 5. 
One-Sample Test

\begin{tabular}{|c|c|c|c|c|c|c|}
\hline & \multicolumn{6}{|c|}{ Test Value $=60$} \\
\hline & \multirow[b]{2}{*}{$\mathrm{T}$} & \multirow[b]{2}{*}{ df } & \multirow[b]{2}{*}{ Sig. (2-tailed) } & \multirow{2}{*}{$\begin{array}{l}\text { Mean } \\
\text { Difference }\end{array}$} & \multicolumn{2}{|c|}{$\begin{array}{l}95 \% \text { Confidence Interval of the } \\
\text { Difference }\end{array}$} \\
\hline & & & & & Lower & Upper \\
\hline skor total & 14.862 & 61 & .000 & 23.968 & 20.74 & 27.19 \\
\hline
\end{tabular}

Tabel 4. 27 One-Sample Test

Dari tabel one-sample test $\mathrm{di}$ atas diperoleh hasil t-hitung $=14,862$. T-tabel diperoleh dengan $\mathrm{df}=61$, Sig.5\% (2-tailed $)=1,999$, karena $t$-tabel $<\mathrm{t}$-hitung $(1,999<14,862)$ maka hipotesis nol $\left(\mathrm{H}_{\mathrm{a}}\right)$ yang berbunyi: Diduga pengembangan strategi pembelajaran yang efektif masa pandemi COVID 19 di Sekolah Tinggi Teologi Kristus Alfa Omega Semarang dalam kategori sedang atau kurang (<) 60\% dari nilai maksimal ditolak. Hipotesis alternatif $\left(\mathrm{H}_{0}\right)$ yang berbunyi: Diduga pengembangan strategi pembelajaran yang efektif masa pandemi COVID 19 di Sekolah Tinggi Teologi Kristus Alfa Omega Semarang dalam kategori lebih besar dari atau sama dengan $(\geq) 60 \%$ dari nilai maksimal diterima.

Setelah melakukan uji signifikansi (uji t), selanjutnya akan dilakukan uji hipotesis dengan menggunakan nilai hipotesis yang diperoleh dari perbandingan $\mu_{0}$ dengan rata-rata nilai empiris, kemudian untuk melihat nilai variabel strategi pembelajaran yang efektif masa pandemi COVID 19 di Sekolah Tinggi Teologi Kristus Alfa Omega Semarang, maka dilakukan dengan cara skor empiris dibagi dengan skor ideal dikali 100\%. Hasil uji hipotesis dapat dilihat sebagai berikut:

$\mu_{0}=($ Nilai Hipotesis $) \times($ Mean Skor Ideal $)$

keterangan:

nilai hipotesis $\quad=60 \%$

Mean skor ideal $=($ skor tertinggi tiap item $) \times($ jumlah item variabel $) \times($ jumlah responden $): \mathrm{N}$

$$
\begin{aligned}
& =(5 \times 21 \times 62): 62 \\
& =6510: 60 \\
& =108 \\
& \quad \mu_{0}=(60 \%) \times 108 \\
& =65
\end{aligned}
$$

Jadi nilai yang di hipotesis $\left(\mu_{0}\right)$ dari variabel strategi pembelajaran yang efektif masa pandemi COVID 19 di Sekolah Tinggi Teologi Kristus Alfa Omega Semarang adalah 60\% atau sama dengan 65.

Selanjutnya dilakukan perhitungan nilai rata-rata empiris (mean skor empiris), adapun hasilnya seperti di bawah ini:

Mean skor empiris $\quad=$ (total skor empiris) : (Jumlah Responden) 


$$
\begin{aligned}
& =5206: 62 \\
& =84
\end{aligned}
$$

Berdasarkan perbandingan nilai $\mu_{0}$ adalah $60 \%$ atau sama dengan 65 , sedangkan mean skor empiris adalah 84 . Dengan demikian diketahui bahwa nilai hipotesis $\left(\mu_{0}\right)$ atau sama dengan 65 , tidak sama dengan nilai skor empris yaitu 84 artinya nilai skor empiris terbukti lebih besar dari nilai hipotesis $\left(\mu_{0}\right)$. Jadi, hipotesis yang berbunyi bahwa tingkat pengembangan strategi pembelajaran yang efektif masa pandemi COVID 19 di Sekolah Tinggi Teologi Kristus Alfa Omega Semarang dalam kategori sedang atau kurang $(<) 60 \%$ dari nilai maksimal, adalah tidak diterima atau tidak sama dengan $60 \%$.

Selanjutnya untuk mengetahui tingkat pengembangan strategi pembelajaran yang efektif masa pandemi COVID 19 di Sekolah Tinggi Teologi Kristus Alfa Omega Semarang dapat dilakukan dengan cara berikut:

$$
\text { Harga \% Variabel } \mathrm{X}=\begin{aligned}
& \sum \text { Skor Empiris } \\
& \sum \text { Skor Ideal }
\end{aligned} \times 100 \%
$$

Keterangan:

Total skor empiris $\quad=$ skor total data variabel $=5206$

Toal skor ideal $=($ skor tertinggi tiap item $) \times($ jumlah item variabel $\mathrm{X}) \times($ jumlah responden $)$

$$
\begin{aligned}
& =5 \times 21 \times 62 \\
& =6510
\end{aligned}
$$

Harga \% Variabel X $=(5206: 6510) \times 100 \%$

$$
=80 \%
$$

Berdasarkan perhitungan diatas diperoleh nilai persentase pengembangan strategi pembelajaran yang efektif masa pandemi COVID 19 di Sekolah Tinggi Teologi Kristus Alfa Omega Semarang adalah 80\% selanjutnya nilai ini akan diinterpretasikan dengan tabel interpretasi hipotesis di bawah ini:

\begin{tabular}{|l|l|}
\hline Prosentase & Makna \\
\hline $0-20$ & Sangat Baik \\
\hline $21-40$ & Tidak Baik \\
\hline $41-60$ & Cukup \\
\hline $61-80$ & Baik \\
\hline $81-100$ & Sangat Baik \\
\hline
\end{tabular}

Tabel 4.28 Pedoman untuk Interpretasi makna prosentasi deskriptif ${ }^{34}$

Berdasarkan tabel di atas maka nilai pengembangan strategi pembelajaran yaitu $80 \%$ adalah Baik (61$80)$.

${ }^{34}$ Gidion, Gidion. "Kecakapan Lulusan Pendidikan Tinggi Teologi Menghadapi Kebutuhan Pelayanan Gereja dan Dunia Pendidikan Kristen." KURIOS (Jurnal Teologi dan Pendidikan Agama Kristen) 6.1 (2020): 73-86. 


\section{Mengembangkan Produk Berdasarkan Temuan}

Strategi pembelajaran yang efektif di tengah masa pandemi COVID 19 di Sekolah Tinggi Teologi Kristus Alfa Omega Semarang adalah strategi pembelajaran yang menggunakan teknologi. Penggunaan teknologi ini ada dalam berbagai komponen-komponen strategi pembelajaran; tujuan pembelajaran, materi pembelajaran, proses pembelajaran, metode, sumber belajar, serta evaluasi. Dosen dan mahasiswa memiliki kemampuan untuk menggunakan teknologi yang disepakati dalam proses pembelajaran.

\section{Pengujian Untuk Menggunakan Produk}

Pengujian dilakukan dengan menyebarkan angket kepada responden dan hasil temuannya sama dengan hasil temuan awal. Hal ini berarti strategi pembelajaran yang menggunakan teknologi dalam segala komponen strategi pembelajaran seperti tujuan pembelajaran, materi pembelajaran, proses pembelajaran, metode, sumber belajar, serta evaluasi merupakan strategi pembelajaran yang efektif di tengah pandemi COVID 19 di Sekolah Tinggi Teologi Kristus Alfa Omega Semarang.

\section{Revisi Produk Yang Akan Digunakan}

Beberapa hal yang direvisi guna perbaikan produk yaitu strategi pembelajaran di tengah pandemi COVID 19 di Sekolah Tinggi Teologi Kristus Alfa Onega Semarang adalah komponen dosen harus mengingkatkan kinerja dengan mengembalikan hasil evaluasi tugas mahasiswa menggunakan teknologi. Dosen harus menggunakan metode problem solving sebagai salah satu metode yang dapat digunakan dalam pembelajaran daring. Dosen juga harus menggunakan metode demonstrasi dalam proses pembelajaran.

\section{KESIMPULAN}

Berdasarkan penelitian yang dilakukan, peneliti menyimpulkan bahwa tingkat pengembangan strategi pembelajaran yang efektif masa pandemi COVID 19 di Sekolah Tinggi Teologi Kristus Alfa Omega Semarang dalam kategori sedang atau kurang $(<)$ 60\% dari nilai maksimal dalam penelitian ini tidak terbukti. Sebab nilai hipotesis yang diperoleh adalah sebesar $80 \%$ yang berada pada kategori tinggi yaitu Baik (61-80). Strategi pembelajaran yang efektif di tengah masa pandemi COVID 19 di Sekolah Tinggi Teologi Kristus Alfa Omega Semarang adalah strategi pembelajaran yang menggunakan teknologi. Penggunaan teknologi ini ada dalam berbagai komponenkomponen strategi pembelajaran antara lain tujuan pembelajaran, materi pembelajaran, proses pembelajaran, metode, sumber belajar, dan evaluasi. Dosen dan mahasiswa memiliki kemampuan untuk menggunakan teknologi yang disepakati dalam proses pembelajaran. Produk strategi pembelajaran di tengah pandemi COVID 19 di Sekolah Tinggi Teologi Kristus Alfa Onega Semarang yang perlu diperbaiki adalah komponen dosen yang harus mengingkatkan kinerja dengan 
mengembalikan hasil evaluasi tugas mahasiswa menggunakan teknologi. Dosen harus menggunakan metode problem solving sebagai salah satu metode yang dapat digunakan dalam pembelajaran daring. Dosen juga harus menggunakan metode demonstrasi dalam proses pembelajaran. 


\section{DAFTAR PUSTAKA}

Ageyev, Vladimir S, Boris Gindis, Suzanne M Miller. Vygotsky's Educational Theory In Cultural Context. UK: Cambridge University Press, 2003.

Ali, M. Penelitian Pendidikan (Prosedur dan Strategis). Bandung: Angkasa, 1985.

Askell-Williams, Hellen, Janice Orrell. "Problem Solving For Teaching and Learning”. London: Taylor and Francis Ltd, 2019.

Blegur, Jusuf. Soft Skill Untuk Prestasi Belajar. Surabaya: Scopindo Media Pustaka, 2020.

Darmadi, H. Pengembangan Model dan Metode Pembelajaran dalam Dinamika Belajar Siswa. Sleman: Deepublish, 2017.

Gunawan, Cakti Indra. Pedoman Menulis Buku Ajar dan Referensi Bagi Dosen. Malang: IRDH, 2017.

Gidion, Gidion. "Kecakapan Lulusan Pendidikan Tinggi Teologi Menghadapi Kebutuhan Pelayanan Gereja dan Dunia Pendidikan Kristen." KURIOS (Jurnal Teologi dan Pendidikan Agama Kristen) 6.1 (2020): 73-86.

Hairun, Yahya. Evaluasi dan Penilaian dalam Pembelajaran. Yogyakarta: Deepublish, 2020.

Handika, Jeffry, dkk. Pembelajaran Sains di Era Akselerasi Digital. Magetan: CV AE Media Grafika, 2020.

Imanudin, Muhamad. Membuat Kelas Online Berbasis Android dengan Google Classroom. Yogyakarta: Garudhawaca, 2018.

Ismail, Ilyas. Assesmen dan Evaluasi Pembelajaran. Makassar: Cendekia Publisher, 2020.

Jihad, Suyanto Asep. Menjadi Guru Profesional. Jakarta, Essensi Erlangga Group, 2013.

Junaeidy, Abdul Moeis. Guru Asyik, Murid Fantastik!. Diva Press, 2018.

Kelana, Kenang. Pedagogik dan Covid 19. Jakarta: Taman Pembelajar Rawamangun, 2002.

Maryanto, Daniel Agus. Jurnal Pendidikan Empiris Edisi : Juni 2018. Solo: CV Akademika, 2018.

Mastuti, Rini, dkk. Teaching From Home: dari Belajar Merdeka Menuju Merdeka Belajar.Yayasan Kita Menulis, 2020.

Miarso, Yusufhadi. Menyemai Benih Teknologi Pendidikan. Jakarta: Prenadamedia Group, 2004.

Muis, Abdul. 'Konsep dan Strategi Pembelajaran di Era Revolusi Industri 4.0. Yogyakarta: Laksana, 2019.

Nugroho, Didiek Hari. Panduan Praktis Membuat dan Memublikasi Video Bahan Ajar. Yogyakarta: Deepublish, 2018.

Prawiradilaga, Dewi Salma. Mozaik Teknologi Pembelajaran: E-Learning. Jakarta: Prenadamedia Group, 2016.

Pribadi, Benny A. Desain dan Pengembangan Program Pelatihan Berbasis Kompetensi Implementasi. Jakarta: Prenada Media Grup, 2014.

Sanjaya, Ridwan. 21 Refleksi Pembelajaran Daring di Masa Darurat. Semarang: UNIKA Soegijapranata, 2020.

Saputro, Budiyono. Manajemen Penelitian Pengembangan. Yogyakarta: Aswaja Pressindo, 2011.

Suardi, Moh. Belajar dan Pembelajaran. Yogyakarta: Deepublish, 2018.

Sudarsana, I Ketut. Covid 19: Perspektif Pendidkan. Yayasan Kita Menulis, 2020.

Susilana, Rudi. Ilmu dan Aplikasi Pendidikan. INTIMA, 2007.

Sutarti, Tatik dan Edi Irawan. Kiat Sukses Meraih Hibah Penelitian Pengembangan. Yogyakarta: Deepublish, 2017.

Watriantos, Ronald, dkk. Belajar dari Covid 19: Perspektif Teknologi dan Pertanian. Yayasan Kita Menulis.

www.chillaword.com diakses tanggal 1 Juni 2020 